\title{
Immunodiagnosis of human neurocysticercosis by using semi- purified scolex antigens from Taenia solium cysticerci
}

\author{
Imunodiagnóstico da neurocisticercose humana usando antígenos \\ semipurificados de escolex de cisticercos de Taenia solium
}

\author{
Francesco Iudici Neto ${ }^{3}$, Geraldo Pianetti-Filho ${ }^{2}$, Ricardo Nascimento Araújo ${ }^{1}$ \\ and Evaldo Nascimento ${ }^{1}$
}

\begin{abstract}
Crude antigen and semi-purified proteins from scolices of Taenia solium cysticerci were evaluated for the immunodiagnosis of buman neurocysticercosis neurocysticercosis. Semi-purified proteins obtained by electrophoresis on polyacrylamide gel and by electroelution were tested by means of the immunoenzymatic reaction against sera from normal individuals and from patients with neurocysticercosis or other parasitic diseases. The 100kDa protein provided 100\% sensitivity and specificity in the immunodiagnosis. When 95 or $26 k D a$ proteins were used, 95 and 100\% sensitivity and specificity were obtained, respectively. The assays involving crude antigen and sera from normal individuals or from patients with neurocysticercosis, diluted to 1:256, gave excellent agreement with those in which 100, 95 or 26kDa proteins were tested against the same serum samples diluted to 1:64. (Kappa: 0.95 to 1.00). Crude scolex antigen may be useful for serological screening, while 100, 95 or 26kDa protein can be used in confirmatory tests on neurocysticercosis-positive cases.
\end{abstract}

Key-words: Taenia solium. Human neurocysticercosis. Semi-purified proteins. Immunodiagnosis.

\section{RESUMO}

Antígeno bruto e proteínas semipurificadas de escóleces de cisticercos de Taenia solium foram avaliados para o imunodiagnóstico da neurocisticercose humana neurocisticercose. As proteinas semipurificadas, obtidas por eletroforese em gel de poliacrilamida e eletroeluição, foram testadas na reação imunoenzimática contra soros de indivíduos normais e de pacientes com neurocisticercose ou outras parasitoses. A proteina de 100kDa proporcionou 100\% de sensibilidade e especificidade no imunodiagnóstico. Quando a proteína de 95 ou $26 k D a$ foi empregada, foram obtidos 95 e 100\% de sensibilidade e especificidade, respectivamente. Os ensaios envolvendo antígeno bruto e soros de indivíduos normais ou de pacientes com neurocisticercose, diluídos a 1:256, tiveram ótima concordância com aqueles onde a proteína de 100, 95 ou 25kDa foi testada contra os mesmas amostras de soro diluídas a 1:64 (Kappa: 0,95 a 1,00). O antígeno bruto de escolex poderá ser empregado na triagem sorológica enquanto a proteína de 100, 95 ou 26kDa nos testes confirmatórios dos casos positivos de NC.

Palavras-chaves: Taenia solium. Neurocisticercose humana. Proteínas semipurificadas. Imunodiagnóstico.

Cerebral cysticercosis, also known as neurocysticercosis (NC), is the most frequent parasitic infection of the human central nervous system (CNS) and is the main cause of epilepsy in underdeveloped countries $^{10}$. Degenerating larvae may cause severe damage to nerve tissue because of inflammatory reactions surrounding the infected area, with subsequent collagen deposition. Complex hydrocephalic syndrome, edema and further complications because of larvae calcification are also important clinical manifestations, and these lead to neurological disorders ${ }^{1435}$.
Neurocysticercosis is difficult to diagnose because of the dimensions, quantities and localization of cysticerci in the CNS. The diagnostic methods include neuroimaging and immunological and histological techniques ${ }^{11}$. Computed tomography and magnetic resonance are formally indicated for diagnosing $\mathrm{NC}$, but the costs relating to these procedures make it difficult for most of the population with high infection rates in developing countries to have access to these services. Moreover, doubts concerning images may occur and auxiliary diagnostic methods are required ${ }^{411}$. Immunoenzymatic tests

\footnotetext{
1. Departamento de Parasitologia, Instituto de Ciências Biológicas, Universidade Federal de Minas Gerais, Belo Horizonte, MG. 2. Departamento de Neurologia, Faculdade de Medicina, Universidade Federal de Minas Gerais, Belo Horizonte, MG. 3. Divisão de Epidemiologia e Controle de Doenças, Instituto Octávio Magalhães, Fundação Ezequiel Dias, Belo Horizonte, MG.

Supported by Coordenação de Aperfeiçoamento de Pessoal de Nível Superior and Fundação de Amparo a Pesquisa de Minas Gerais.

Address to: Prof. Evaldo Nascimento. Depto de Parasitologia//ICB/UFMG. Av. Presidente Antonio Carlos 6627, Pampulha, 31270-901 Belo Horizonte, MG, Brasil.

Fax: 55 31-3499-2859

e-mail: evaldo@icb.ufmg.br

Recebido para publicação em 23/9/2005

Aceito em $8 / 2 / 2007$
} 
(ELISA) have been employed for NC diagnosis due to their high sensitivity, for which cerebrospinal fluid (CSF) may be used as samples. However, considering the difficulties in collecting CSF, which requires specialized physicians in special facilities, serum has been chosen as an alternative source sample ${ }^{6}$. Investigations carried out in the Department of Parasitology of the Institute of Biological Sciences, Federal University of Minas Gerais (ICB/ UFMG) have shown that the best immunogenic proteins for NC immunodiagnosis were in the cysticercus scolices, and these have been used to detect serum or CSF antibodies in patients with suspected $\mathrm{NC}^{2829} 30$.

The broad range of constitutive proteins from cysticerci enhances the perspectives for a variety of studies aimed at identifying and purifying antigens to reach the best sensitivity and specificity indices for NC immunodiagnosis. In the present study, we semi-purified proteins from scolices of Taenia solium cysticerci and assessed their sensitivity and specificity by means of ELISA. Crude antigens from scolices were used as an alternative for selecting positive cases. The possibility of ELISA cross-reactions between the semi-purified proteins and other parasitic infections was also investigated.

\section{MATERIAL AND METHODS}

Human sera. For ELISA sensitivity and specificity tests, 20 serum samples from patients with positive computerized tomography for NC, attended at the Neurology Services of Hospital das Clínicas of UFMG, Belo Horizonte, State of Minas Gerais, Brazil, and 14 negative serum samples from Palo Alto Medical Research Foundation, Palo Alto, USA, were used. For cross-reaction evaluation, samples from the sera collection of the Department of Parasitology of ICB/UFMG were used: 15 serum samples from patients with schistosomiasis mansoni, diagnosed by parasitological tests; 14 serum samples from patients with Toxocara canis larvae, diagnosed by clinical and serological examinations; and six serum samples from patients with American trypanosomiasis, diagnosed by clinical and serological tests. All sera were obtained from individuals and anonymous patients and were used after gaining approval under case number ETIC 223/02, from the UFMG ethics committee for human research.

Scolex from cysticerci. Cysticerci were obtained from naturally infected pigs in the region of Montes Claros, State of Minas Gerais, Brazil. Cysticerci extraction and crude antigen preparation from scolices were carried out in accordance with the techniques described by Nascimento et $\mathrm{al}^{28}$.

Protein electrophoresis. Proteins were separated according to their molecular weight on $12.5 \%$ polyacrylamide gels, as described by Laemmli ${ }^{21}$. Standard molecular weights (Sigma, USA) containing a mix of 205, 116, 66 and 29kDa markers were used in all electrophoreses. Gels were stained with $0.25 \%$ Coomassie blue G250 solution (Merck).

Semi-purification of proteins. To obtain semi-purified proteins, 30 preparative gels were used. After staining, bands were viewed and cut with a scalpel. Each band was broken into pieces of approximately $5 \times 5 \mathrm{~mm}$ and placed on dialysis membranes capable of retaining proteins of molecular weights over $8 \mathrm{kDa}$ (3M, USA). Elution buffer solution $\left(50 \mathrm{mM} \mathrm{NH}_{4} \mathrm{HCO}_{3}, 0.1 \% \mathrm{SDS}\right)$ was added to each membrane in sufficient quantity to totally cover the gel pieces. Next, the dialysis membranes were placed in a horizontal electrophoresis vat (Biorad, CA, USA) with running buffer solution (25mM Tris, $200 \mathrm{mM}$ glycine, $3 \mathrm{mM}$ SDS). The proteins were electroeluted at $100 \mathrm{~V}$ DC (direct current), for $1 \mathrm{~h}$ at room temperature. Following this, the membranes with electroeluted proteins were subjected to dialysis in 2 liters of phosphate buffer solution (PBS) at $\mathrm{pH} 7.2\left(8.1 \mathrm{mM} \mathrm{Na}_{2} \mathrm{PO}_{4}, 1.5 \mathrm{mM} \mathrm{KH}_{2} \mathrm{PO}_{4}\right.$, $136 \mathrm{mM} \mathrm{NaCl}$ ) at $4^{\circ} \mathrm{C}$ for $18 \mathrm{~h}$, with buffer solution changes and two repetitions of the procedure. The supernatant liquids containing electroeluted proteins were removed and transferred to other dialysis membranes, and then concentrated to a volume of $0.5 \mathrm{ml}$ using crystallized sucrose. The solutions with semi-purified proteins were placed in microcentrifuge tubes and cryopreserved at $-20^{\circ} \mathrm{C}$ until the subsequent procedures. Semi-purification assessment was performed by means of polyacrylamide gel electrophoresis.

Protein measurements. Crude antigen and semi-purified proteins were measured in accordance with Lowry et a $2^{24}$.

Enzyme linked immunosorbent assay. The ELISA test was undertaken with two goals: immunogenic protein screening and sensitivity and specificity tests. Polyethylene microplates (Alamar, Italy) were sensitized using a standardized quantity of $2 \mu \mathrm{g}$ of each protein, diluted in $100 \mu \mathrm{l}$ carbonate buffer at $\mathrm{pH} 9.6$ $\left(15 \mathrm{mM} \mathrm{Na}_{2} \mathrm{CO}_{3}, 35 \mathrm{mM} \mathrm{NaHCO}_{3}\right)$ and then incubated for $18 \mathrm{~h}$ at $4^{\circ} \mathrm{C}$. After incubation, the microplates were manually washed six times in PBS at pH 7.2, containing 0.05\% Tween 20. Plastic active sites were blocked by incubating the plates at $37^{\circ} \mathrm{C}$ for 30 min, with $2 \%$ casein solution in PBS at $\mathrm{pH} 7.2$. The microplate wells were washed again six times in PBS at $\mathrm{pH} 7.2$ with $0.05 \%$ Tween. Screening for immunogenic proteins was carried out using a serum pool from 20 patients with $\mathrm{NC}$ and another serum pool from 14 normal individuals diluted at 1:80 in PBS at pH 7.2, with $0.05 \%$ Tween and $1 \%$ casein. For sensitivity and specificity evaluations, sera from normal individuals, patients with NC and patients with other parasitic infections were diluted from 1:32 to $1: 4,096$, at a ratio of $1: 2$, in the same buffer. Diluted sera were added to the sensitized microplates at a volume of $100 \mu l$ per well.

Microplates with diluted sera were incubated at $37^{\circ} \mathrm{C}$ for $60 \mathrm{~min}$ and then washed six times in PBS with $0.05 \%$ Tween. Following this procedure, $100 \mu \mathrm{l}$ of human anti-IgG conjugated to peroxidase (Sigma, USA) were put in the wells, diluted at 1:3,000 in PBS at pH 7.2, with $2 \%$ casein and $0.05 \%$ Tween. The microplates were then incubated at $37^{\circ} \mathrm{C}$ for $45 \mathrm{~min}$ and washed six times in PBS at $\mathrm{pH} 7.2$ with $0.05 \%$ Tween. The reaction was developed by adding phosphate-citrate buffer solution $(46 \mathrm{mM}$ citric acid, $100 \mathrm{mM} \mathrm{Na}_{2} \mathrm{PO}_{4}$ ) to each well, containing $0.03 \%$ orthophenylenediamine (OPD) (Merck) and $0.04 \%$ hydrogen peroxide (30 volumes) (Merck), which was freshly prepared at the time of use. The microplates were incubated at room temperature for 15 min in a dark chamber. The reaction was interrupted by adding 
$30 \mu \mathrm{l}$ of $4 \mathrm{~N}$ sulfuric acid. Absorbance readings were performed in a spectrophotometer for microplates (Biorad 3550, CA, USA), using a wavelength of 492nm.

Positive and negative controls, in triplicates, were added to all microplates, as well as blank controls (Column A, in which antigen was not placed) and conjugated controls (wells in which serum was not placed).

To select the immunogenic proteins, the calculations described by Rajasekariah et al ${ }^{32}$ were used. In these, the Abs+/Abs- ratio was established for each protein studied: Abs+ represented ELISA absorbance with a positive serum pool and Abs- represented absorbance with a negative serum pool. The highest indices resulting from these calculations served as indicators for the best immunogenic proteins to be used for sensitivity and specificity tests.

In the sensitivity and specificity tests, the reaction cutoff for each microplate was considered using the formula $X+3 S$, in which $\mathrm{X}$ corresponded to the mean and $\mathrm{S}$ to the standard deviation of absorbance from normal controls diluted at 1:32. Titers from positive samples were established by taking into account the last dilution at which the absorbance was shown to be higher than the cutoff value. The results from the cutoff calculations for each dilution were obtained using the Microsoft Excel software, integrated in the Office 2000 suite.

Statistical analysis. The ELISA absorbance for selecting immunogenic proteins from positive and negative serum pools was compared using the non-parametric Wilcoxon signed-ranks test for matching pairs, by means of the Minitab version 13 statistical software. The null hypothesis was rejected when $\mathrm{p}<0.05$. To calculate sensitivity and specificity indices from the test results, sera from patients with $\mathrm{NC}$ and from normal individuals were used, respectively. Sensitivity and specificity indices were calculated for each serum dilution. To calculate agreement indices between the ELISA results, kappa statistics $(k)$ with $95 \%$ confidence interval $\left(\mathrm{CI}_{95 \%}\right)$ were applied using the Microsoft Excel software.

\section{RESULTS}

Electrophoresis of crude antigens and semi-purified proteins. The electrophoresis profile for crude antigens from scolices of T. solium cysticerci showed at least 21 bands of major proteins, for which the molecular weights (in decreasing order) ranged from 200 to $15 \mathrm{kDa}$. Electrophoresis of the semi-purified major proteins demonstrated bands of 200, 180, 120, 100, 95, $80,68,65,56,53,50,45,40,38,36,34,29,26,22,20$ and $15 \mathrm{kDa}$ (Figure 1).

Selection of immunogenic proteins. The ELISA absorbance ratio from the positive and negative serum pools showed that proteins with the molecular weights of 200, 180, 120, $100,95,68,65$ and 26kDa were the most reactive (Figure 2). The absorbance difference relating to these proteins was statistically significant $(\mathrm{p}=0.014)$ when tested against the positive and negative serum pools. On the other hand, this difference was not observed $(\mathrm{p}=0.249)$ when the $80,56,53,50,45,40,38,36,34,29,22$,

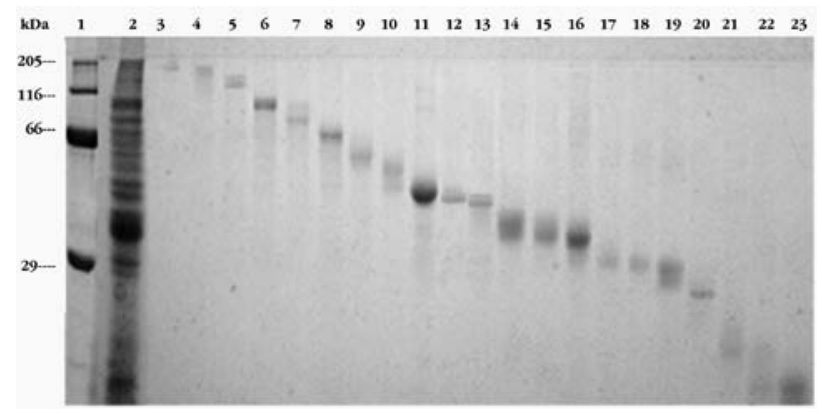

Figure 1 - 12.5\% polyacrylamide gel electrophoresis (SDS-PAGE) with crude antigen and proteins semi-purified from scolices of Taenia solium cysticerci. Lane 1-Standard molecular weight (kDa); Lane 2-Crude antigen; Lanes 3 to 23-Semi-purified proteins (kDa): 3-200; 4-180; 5 120; 6-100; 7-95; 8-80; 9-68; 10-65; 11-56; 12-53; 13-50; 14-45; 15-40; 16-38; 17-36; 18-34; 19-29; 20-26; 21-22; 22-20; 23-15.

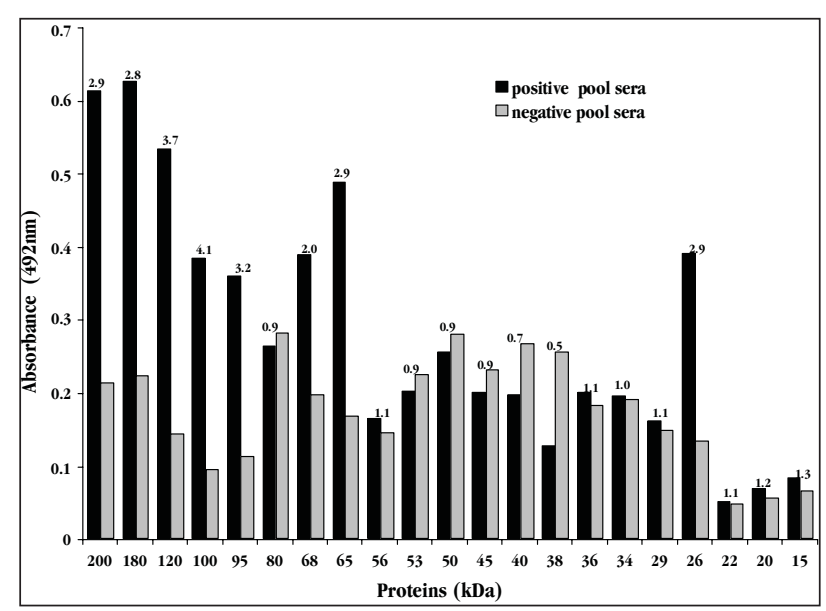

Figure 2 - ELISA absorbance values assayed for IgG antibodies using semi-purified proteins from scolices of Taenia solium cysticerci, negative and positive serum pools for neurocysticercosis diluted at 1:80. The microplate was sensitized with $2 \mu \mathrm{g}$ of each protein. The results from the ratio between the absorbance values are above the bars.

20 and $15 \mathrm{kDa}$ proteins were used, and for this reason they were not included in the sensitivity and specificity tests.

Evaluation of crude antigen and semi-purified proteins. Crude antigen reacted with sera from patients with NC at dilutions ranging from 1:32 to 1:2,048. Nonspecific reactions were observed between crude antigen and six normal sera at a maximum titer of 1:128. Semi-purified proteins reacted with sera from patients with $\mathrm{NC}$ at titers that were not more dilute than 1:1,024. All semi-purified proteins reacted nonspecifically with at least one of the normal sera, at titers that ranged from 1:32 to 1:128 (Table 1).

Table 2 shows the results from the calculations of sensitivity and specificity indices for each serum titer that was tested for crude and semi-purified proteins from the scolices of T. solium cysticerci. Sensitivity of 0.95 and specificity of 1.00 were observed when crude antigen was simultaneously tested with sera from normal individuals and patients with NC diluted at 1:256. The maximum sensitivity and specificity indices (1.00) were only observed when the $100 \mathrm{kDa}$ protein was tested with sera diluted at 1:64. Indices approximating to this value were observed when 120,95 and $26 \mathrm{kDa}$ proteins were tested with sera diluted 
Table 1 - Seric IgG titers of ELISA tests using crude antigen and semipurified proteins from scolices of Taenia solium cysticerci.

\begin{tabular}{|c|c|c|c|c|c|c|c|c|c|}
\hline \multirow{2}{*}{$\begin{array}{l}\text { Proteins } \\
(\mathrm{kDa})\end{array}$} & \multirow[b]{2}{*}{ Sera } & \multicolumn{8}{|c|}{ Titers } \\
\hline & & NR & 32 & 64 & 128 & 256 & 512 & 1,024 & 2,048 \\
\hline \multirow[t]{2}{*}{ Crude } & $\mathrm{NC}$ & - & - & - & 1 & 5 & 5 & 7 & 2 \\
\hline & $\mathrm{N}$ & 8 & 3 & 2 & 1 & - & - & - & - \\
\hline \multirow[t]{2}{*}{200} & $\mathrm{NC}$ & 1 & 5 & 6 & 2 & 5 & 1 & - & - \\
\hline & $\mathrm{N}$ & 10 & 4 & - & - & - & - & - & - \\
\hline \multirow[t]{2}{*}{180} & $\mathrm{NC}$ & - & - & 2 & 2 & 10 & 6 & - & - \\
\hline & $\mathrm{N}$ & 8 & 2 & 4 & - & - & - & - & - \\
\hline \multirow[t]{2}{*}{120} & $\mathrm{NC}$ & - & 1 & 5 & 4 & 7 & 3 & - & - \\
\hline & $\mathrm{N}$ & 3 & 5 & 5 & 1 & - & - & - & - \\
\hline \multirow[t]{2}{*}{100} & $\mathrm{NC}$ & - & - & 1 & 1 & 17 & 1 & - & - \\
\hline & $\mathrm{N}$ & 12 & 2 & - & - & - & - & - & - \\
\hline \multirow[t]{2}{*}{95} & $\mathrm{NC}$ & - & 1 & 1 & 4 & 8 & 3 & 3 & - \\
\hline & $\mathrm{N}$ & 12 & 2 & - & - & - & - & - & - \\
\hline \multirow[t]{2}{*}{68} & $\mathrm{NC}$ & 1 & 3 & 4 & 4 & 6 & 2 & - & - \\
\hline & $\mathrm{N}$ & 8 & 2 & 2 & 2 & - & - & - & - \\
\hline \multirow[t]{2}{*}{65} & $\mathrm{NC}$ & 1 & 1 & 5 & 4 & 8 & 1 & - & - \\
\hline & $\mathrm{N}$ & 9 & 5 & - & - & - & - & - & - \\
\hline \multirow[t]{2}{*}{26} & $\mathrm{NC}$ & - & 1 & 1 & 3 & 13 & 2 & - & - \\
\hline & $\mathrm{N}$ & 13 & 1 & - & - & - & - & - & - \\
\hline
\end{tabular}

NC: Neurocysticercosis (20); N: Normal (14); NR: Non reactive

at 1:64 (sensitivity of 0.95 and specificity of 1.00 ). The other semi-purified proteins did not provide greater indices in any of the serum dilutions used.

Cross-reactions between crude antigen and sera from patients with other parasitic infections were only avoided when the samples were diluted at 1:1,024. In solutions less dilute than 1:1,024, 9/20 (45\%) of the sera from patients with $\mathrm{NC}$ reacted with crude antigen (Figure 3).

The semi-purified $120 \mathrm{kDa}$ protein only presented no reaction with sera from patients with other parasitical infections when the solution was more dilute than 1:128. When the titer was less dilute than this, $10 / 20(50 \%)$ of the sera from patients with $\mathrm{NC}$ reacted with it. Proteins of 100 and $26 \mathrm{kDa}$ were respectively recognized by $20 / 20(100 \%)$ and $19 / 20(95 \%)$ of the sera from
Table 2 - Sensitivity and specificity indices from ELISA using crude antigen or semi-purified proteins extracted from scolices of Taenia solium cysticerci. Different dilutions of the serum samples from normal individuals and patients with neurocysticercosis were used.

\begin{tabular}{|c|c|c|c|c|c|c|c|c|c|}
\hline \multirow{2}{*}{$\begin{array}{l}\text { Protein } \\
(\mathrm{kDa})\end{array}$} & \multirow{2}{*}{$\begin{array}{l}\mathrm{s} \\
\text { Indices }\end{array}$} & \multicolumn{7}{|c|}{ Titers } & \multirow[b]{2}{*}{4,096} \\
\hline & & 32 & 64 & 128 & 256 & 512 & 1,024 & 2,048 & \\
\hline \multirow[t]{2}{*}{ Crude } & sen & 1.00 & 1.00 & 1.00 & 0.95 & 0.70 & 0.45 & 0.10 & - \\
\hline & spe & 0.57 & 0.79 & 0.93 & 1.00 & 1.00 & 1.00 & 1.00 & 1.00 \\
\hline \multirow[t]{2}{*}{200} & sen & 0.95 & 0.70 & 0.40 & 0.30 & 0.05 & - & - & - \\
\hline & spe & 0.71 & 1.00 & 1.00 & 1.00 & 1.00 & 1.00 & 1.00 & 1.00 \\
\hline \multirow[t]{2}{*}{180} & sen & 1.00 & 1.00 & 0.90 & 0.80 & 0.30 & - & - & - \\
\hline & spe & 0.57 & 0.71 & 1.00 & 1.00 & 1.00 & 1.00 & 1.00 & 1.00 \\
\hline \multirow[t]{2}{*}{120} & sen & 1.00 & 0.95 & 0.70 & 0.50 & 0.15 & - & - & - \\
\hline & spe & 0.79 & 1.00 & 1.00 & 1.00 & 1.00 & 1.00 & 1.00 & 1.00 \\
\hline \multirow[t]{2}{*}{100} & sen & 1.00 & 1.00 & 0.95 & 0.90 & 0.05 & - & - & - \\
\hline & spe & 0.86 & 1.00 & 1.00 & 1.00 & 1.00 & 1.00 & 1.00 & 1.00 \\
\hline \multirow[t]{2}{*}{95} & sen & 1.00 & 0.95 & 0.90 & 0.70 & 0.30 & 0.15 & - & - \\
\hline & spe & 0.86 & 1.00 & 1.00 & 1.00 & 1.00 & 1.00 & 1.00 & 1.00 \\
\hline \multirow[t]{2}{*}{68} & sen & 0.95 & 0.80 & 0.60 & 0.40 & 0.10 & - & - & - \\
\hline & spe & 0.57 & 0.71 & 0.86 & 1.00 & 1.00 & 1.00 & 1.00 & 1.00 \\
\hline \multirow[t]{2}{*}{65} & sen & 0.95 & 0.90 & 0.65 & 0.45 & 0.05 & - & - & - \\
\hline & spe & 0.64 & 1.00 & 1.00 & 1.00 & 1.00 & 1.00 & 1.00 & 1.00 \\
\hline \multirow[t]{2}{*}{26} & sen & 1.00 & 0.95 & 0.90 & 0.75 & 0.10 & - & - & - \\
\hline & spe & 0.93 & 1.00 & 1.00 & 1.00 & 1.00 & 1.00 & 1.00 & 1.00 \\
\hline
\end{tabular}

sen: sensitivity; spe: specificity

patients with NC, at a cut-off dilution of 1:64. The $95 \mathrm{kDa}$ protein was only specifically recognized by $18 / 20(90 \%)$ of sera from patients with $\mathrm{NC}$, when diluted at 1:128, a titer that allowed us to eliminate cross-reactions (Figure 4).

The results showed in Table 1 were analyzed statistically to investigate the agreement indices between the ELISA using sera from NC and normal patients against crude antigen or semi-purified proteins. The reactions using sera diluted at 1:256 and crude antigens provided very high agreement with the reactions in which the same serum samples diluted at 1:64 were tested against the semi-purified protein of $100 \mathrm{kDa}\left(k=0.95 ; \mathrm{CI}_{95 \%}=0.82-1.06\right), 95 \mathrm{kDa}(k=1.00$; $\left.\mathrm{CI}_{95 \%}=1.00-1.00\right)$ or $26 \mathrm{kDa}\left(k=1.00 ; \mathrm{CI}_{95 \%}=1.00-1.00\right)$.

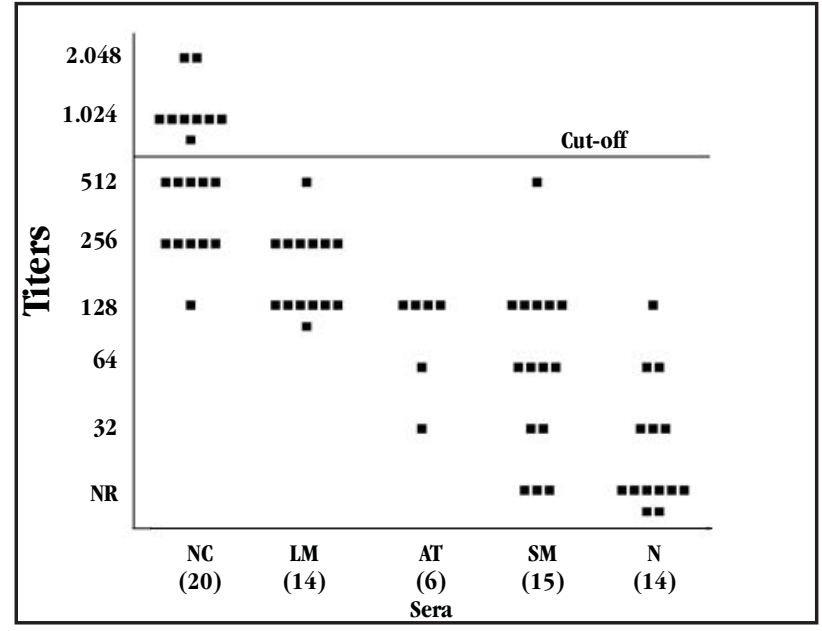

Figure 3-Seric IgG titers of ELISA usingsamples from patientswithneurocysticencosis(NC), Toxocara canis larva migrans (LM), American trypanosomiasis (AT) or schistosomiasis mansoni (SM) and samples from normal individuals (N). Microplates were sensitized with crude antigen extracted from scolices of Taenia solium cysticerci. 


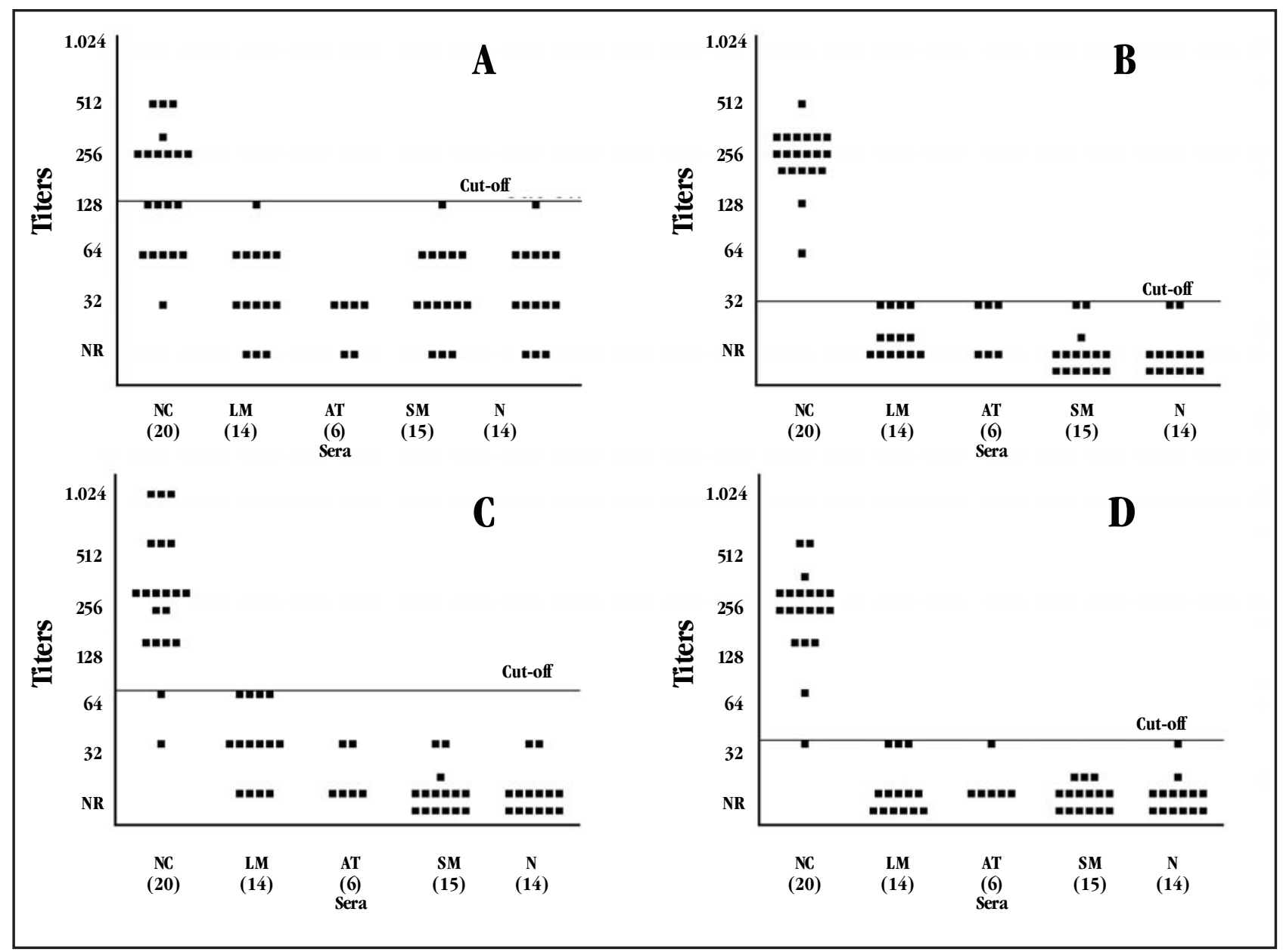

Figure 4 - Seric IgG titers of ELISA using samples from patients with neurocysticercosis (NC), Toxocara canis larva migrans (LM), American trypanosomiasis (AT) or schistosomiasis mansoni (SM) and samples from normal individuals(N). Microplates were sensitized with semi-purified proteins of 120kDa (a), 100kDa (b), 95kDa (c) or 26kDa (d) from scolices of Taenia solium cysticerci.

\section{DISCUSSION}

Neurocysticercosis is characterized by a strong immune response surrounding infected neural tissues ${ }^{3}$. The presence of excretion-secretion antigens and proteins released by the degeneration of the cysticerci in the host stimulates the production of specific immunoglobulins in which the isotopic predominance is related to the infection phase ${ }^{127}$. Anti-cysticerci $\operatorname{IgG}$ is the one most detected in both the acute and the chronic phases of the disease $^{7232631}$. Therefore, in addition to the semi-purified antigens, we used human anti-IgG antibodies for the immunoassays in order to reach higher sensitivity and specificity indices, even for patients in different phases of the disease.

The present study showed that most of the proteins semipurified from cysticerci scolices did not showed good sensitivity and specificity indices and just some could be indicated as antigens for NC immunodiagnosis. The low specificity found in tests using proteins with different molecular weights possibly occurred due to the antigenic similarity between the cysticerci, the adults of T. solium and other helminthes. This similarity might predict the occurrence of cross-reactions when sera from patients free from $\mathrm{NC}$, but with other parasitic diseases, including taeniasis, are tested $^{18}$. Studies using sera from patients with infections caused by viruses, bacteria or protozoa have also shown nonspecific reactions when tested against T. solium antigens ${ }^{5825}$. These findings increase the difficulty of antigen evaluation and subsequent use for NC immunodiagnosis, since sera from patients with different diseases should be analyzed. Despite the diversity of nonspecific reactions and cross-reactions, the present study has contributed towards elucidating the possibility of such events occurring between the semi-purified antigens and the available sera from normal individuals and patients with Toxocara canis larva migrans, American trypanosomiasis or schistosomiasis mansoni.

Previous studies have already shown increased specificity for immunodiagnostic tests by using purified antigens instead of crude antigens ${ }^{193036}$. On the other hand, reports of false-positive results have also been registered, thus suggesting that the use of purified antigens for immunodiagnosis should be done with caution ${ }^{20}$.

In the current study, the 100,95 and 26kDa proteins provided the best sensitivity and specificity indices when the appropriate dilutions of the sera were used. Among these, the 26kDa protein was previously indicated for $\mathrm{NC}$ immunodiagnosis due to its high specificity ${ }^{121519}$. The 100 and $95 \mathrm{kDa}$ proteins are probably similar 
to the antigen $\mathrm{B}$, which is important for inducing an immune response $^{91316}$. Sera from patients with NC used in the present investigation frequently recognized such proteins and, when diluted at 1:64, enabled the best sensitivity and specificity indices from the ELISA tests.

Difficulties in stabilizing proteins, in which their antigenic determinants are kept during the purification stages and subsequent adsorption in polystyrene microplates, have been reported by some investigators and may be important for maintaining antigen-antibody reactivity ${ }^{2}{ }^{1722}$. This might be one of the reasons for the non-reactivity of several low molecular weight proteins that have already been described as immunogenic 8121619333436

Production of crude antigen from T. solium scolices is possible at low cost and, when tested by ELISA with sera from normal individuals and patients with $\mathrm{NC}$, crude antigen provided results presenting high concordance with those obtained by ELISA using the semi-purified 100, 95, and 26kDa proteins. Therefore, we recommend applying crude antigen in ELISA tests as means of excluding negative cases, particularly for seroepidemiological surveys. Antigens of 100,95 or $26 \mathrm{kDa}$ may be used in ELISA reactions to confirm positive results, using the 1:64 serum dilution, thus eliminating possible cross-reactions as observed in this study.

The major problem involving specific antigen production, using preparative gels and subsequent electroelution, continues to be the small amounts of protein recovered after the whole process. Thus, further studies are necessary, with the aims of producing proteins in satisfactory quantities and achieving their stabilization under conditions in which they remain immunogenic for long periods. Among these possibilities is the production of recombinant proteins, which could also be used for characterizing the genes coding for proteins with molecular weights of 100, 95 and 26kDa from T. solium cysticerci, and for producing synthetic peptides that could be used in validating immunodiagnostic tests.

\section{ACKNOWLEDGEMENTS}

The authors would like to thank the biologist Gláucia Celeste de Souza Amâncio for her critical review of the text, tables and figures; Prof. Renato Martins Assunção, of the Institute of Exact Sciences of UFMG, for statistical analysis assistance; and Alberto Souza de Araújo Júnior for laboratory technical support.

\section{REFERENCES}

1. Abraham R, Pardini AX, Vaz AJ, Livramento JA, Machado LR. Taenia antigens detection in the cerebrospinal fluid of patients with neurocysticercosis and its relationship with clinical activity of the disease. Arquivos de Neuro-Psiquiatria 62:756-760, 2004.

2. Almeida MS, Kurtenbach E. Como purificar proteínas? Biotecnologia Ciência \& Desenvolvimento 24:30-35, 2002.

3. Alvarez JI, Colegial CH, Castaño CA, Trujillo J, Teale JM, Restrepo BI. The human nervous tissue in proximity to granulomatous lesions induced by Taenia solium metacestodes displays an active response. Journal of Neuroimmunology 127:139-144, 2002

4. Amaral L, Maschietto M, Maschietto R, Cury R, Ferreira NF, Mendonça R, Lima SS. Unusual manifestations of neurocysticercosis in MR imaging: analysis of 172 cases Arquivos de Neuro-Psiquiatria 61:533-541, 2003.

5. Arruda GC, Silva ADT, Quagliato EMAB, Maretti MA, Rossi CL. Evaluation of Taenia solium and Taenia crassiceps cysticercal antigens for the serodiagnosis of neurocysticercosis. Tropical Medicine and International Heath 10:1005-1012, 2005.

6. Barcelos ISC, Ferreira MS, Moura LP, Biondi GF, Costa-Cruz JM. Use of the paired samples (cerebrospinal fluid and serum) in immunodiagnostic of active and inactive human neurocysticercosis. Memórias do Instituto Oswaldo Cruz 100:427-429, 2005

7. Bueno EC, Vaz AJ, Machado LR, Livramento JA. Neurocysticercosis: detection of IgG, IgA and IgE antibodies in cerebrospinal fluid, serum and saliva samples by ELISA with Taenia solium and Taenia crassiceps antigens. Arquivos de NeuroPsiquiatria 58:18-24, 2000.

8. Bueno EC, Vaz AJ, Machado LR, Livramento JA, Mielle SR. Specific Taenia crassiceps and Taenia solium antigenic peptides for neurocysticercosis immunodiagnosis using serum samples. Journal of Clinical Microbiology 38:146-151, 2000.

9. Das S, Mahajan RC, Ganguly NK, Sawhney IMS, Dhawan V, Malla N. Detection of antigen B of Cysticercus cellulosae in cerebrospinal fluid for the diagnosis of human neurocysticercosis. Tropical Medicine and International Health 7:53-58, 2002 .

10. Del Brutto OH. Neurocysticercosis. Seminars in Neurology 25:243-251, 2005.

11. Del Brutto OH, Rajshekhar V, White AC Jr, Tsang VC, Nash TE, Takayanagui OM, Schantz PM, Evans CA, Flisser A, Correa D, Botero D, Allan JC, Sarti E, Gonzalez AE, Gilman RH, Garcia HH. Proposed diagnostic criteria for neurocysticercosis. Neurology 57:177-183, 2001.

12. Ev LV, Maia AAM, Pianetti G, Nascimento E. Immunological evaluation of a $26 \mathrm{kDa}$ antigen from Taenia solium larvae for specific immunodiagnosis of human neurocysticercosis. Parasitology Research 85:98-102, 1999.

13. Flisser A, Woodhouse E, Larralde C. Human cysticercosis: antigens, antibodies and non-responders. Clinical Experimental Immunology 39:27-37, 1980.

14. Garcia HH, Del Brutto OH, Nash TE, White AC Jr. New concepts in the diagnosis and management of neurocysticercosis (Taenia solium). The American Journal of Tropical Medicine and Hygiene 72:3-9, 2005.

15. Gottstein B, Tsang VCW, Schantz PM. Demonstration of species-specific and cross-reactive components of Taenia solium metacestode antigens. The American Journal of Tropical Medicine and Hygiene 35:308-313, 1986.

16. Grogl M, Estrada JJ, MacDonald G, Kuhn RE. Antigen-antibody analyses in neurocysticercosis. The Journal of Parasitology 71:433-442, 1985.

17. Houen G, Koch C. A non-denaturing enzyme linked immunosorbent assay with protein preadsorbed onto aluminum hydroxide. Journal of Immunological Methods 200:99-105, 1997.

18. Ishida MM, Rubinsky-Elefant G, Ferreira AW, Hoshino-Shimizu S, Vaz AJ. Helminth antigens (Taenia solium, Taenia crassiceps, Toxocara canis, Schistosoma mansoni and Echinococcus granulosus) and cross-reactivities in human infections and immunized animals. Acta Tropica 89:73-84, 2003.

19. Ito A, Plancarte A, Ma L, Kong Y, Flisser A, Cho SY, Liu YH, Kamhawi S, Lightowlers MW, Schantz PM. Novel antigens for neurocysticercosis: simple method for preparation and evaluation for serodiagnosis. The American Journal of Tropical Medicine and Hygiene 59:291-294, 1998.

20. Kojic EM, White AC Jr. A positive enzyme-linked immunoelectrotransfer blot assay result for a patient without evidence of cysticercosis. Clinical Infectious Diseases 36:e7-9, 2002.

21. Laemmli UK. Cleavage of structural proteins during the assembly of the head bacteriophage T4. Nature 227:680-685, 1970.

22. Lechtzier V, Hutoran M, Levy T, Kotler M, Brenner T, Steinitz M. Sodium dodecyl sulphate-treated proteins as ligands in ELISA. Journal of Immunological Methods 270:19-26, 2002.

23. Lopez JA, Garcia E, Cortes IM, Sotelo J, Tato P, Molinari JL. Neurocysticercosis: relationship between the developmental stage of metacestode present and the 
titre of specific IgG in the cerebrospinal fluid. Annals of Tropical Medicine and Parasitology 98:569-579, 2004.

24. Lowry $\mathrm{OH}$, Rosebrough NJ, Farr AL, Randall RJ. Protein measurement with the Folin phenol reagent. Journal of Biological Chemistry 193:265-275, 1951.

25. Macedo HW, Peralta RHS, Cipriano A, Sarmento MR, Vaz AJ, Peralta JM. Avaliação de testes imunológicos para o diagnóstico da neurocisticercose. Jornal Brasileiro de Patologia e Medicina Laboratorial 38:93-103, 2002.

26. Machado LR, Livramento JA, Vaz AJ, Bueno EC, Mielli SR, Bastouly V, Nóbrega JPS. IgG intrathecal synthesis and specific antibody index in patients with neurocysticercosis. Arquivos de Neuro-Psiquiatria 60:395-399, 2002.

27. Molinari JL, Garcia-Mendoza E, de la Garza Y, Ramírez JA, Sotelo J, Tato P. Discrimination between active and inactive neurocysticercosis by metacestode excretory/secretory antigens of Taenia solium in an enzyme-linked immunosorbent assay. The American Journal of Tropical Medicine and Hygiene 66:777-781, 2002.

28. Nascimento E, Araújo FG. Estudos imunoquímicos em extratos aquosos de larvas e adultos de Taenia solium II - Relacionamento antigênico, padrões cromatográfico, atividade imunológica do escólex. Revista do Instituto de Medicina Tropical de São Paulo 24:359-363, 1982

29. Nascimento E, Nogueira PM, Tavares CA. Improved immunodiagnosis of human cysticercosis with scolex protein antigens. Parasitology Research 73:446-450, 1987.
30. Nascimento E, Tavares CA, Lopes JD. Immunodiagnosis of human cysticercosis (Taenia solium) with antigens purified by monoclonal antibodies. Journal of Clinical Microbiology 25:1181-1185, 1987.

31. Odashima NS, Takayanagui OM, Figueiredo JFC. Enzyme linked immunosorbent assay (ELISA) for the detection of IgG, IgM, IgE, and IgA against Cysticercus cellulosae in cerebrospinal fluid of patients with neurocysticercosis. Arquivos de Neuro-Psiquiatria 60:400-405, 2002.

32. Rajasekariah GHR, Ryan JR, Hillier SR, Yi LP, Stiteler JM, Cui L, Smithyman AM, Martin SK. Optimisation of an ELISA for the serodiagnosis of visceral leishmaniasis using in vitro derived promastigote antigens. Journal of Immunological Methods 252:105-119, 2001

33. Rodriguez-Canul R, Allan JC, Fletes C, Sutisna IP, Kapti IN, Craig PS. Comparative evaluation of purified Taenia solium glycoproteins and crude metacestode extracts by immunoblotting for the serodiagnosis of human T. solium cysticercosis. Clinical and Diagnostic Laboratory Immunology 4:579-582, 1997.

34. Shiguekawa KYM, Mineo JR, Moura LP, Costa-Cruz JM. ELISA and western blotting tests in the detection of IgG antibodies to Taenia solium metacestodes in serum samples in human neurocysticercosis. Tropical Medicine and International Health 5:443-449, 2000.

35. Takayanagui OM, Odashima NS. Clinical aspects of neurocysticercosis. Parasitology International 55:S111-115, 2006.

36. Tsang VCW, Brand JA, Boyer AE. An enzyme-linked immunoelectrotransfer blot assay and glycoprotein antigens for diagnosing human cysticercosis (Taenia solium). The Journal of Infectious Diseases 159:50-59, 1989. 